\title{
Urbanization and biodiversity of arbuscular mycorrhizal fungi: The case study of Delhi, India
}

\author{
Manju M. Gupta ${ }^{1}$, Akshat Gupta $^{2} \&$ Prabhat Kumar $^{1}$ \\ 1. Department of Botany, Sri Aurobindo College, University of Delhi, Malviya Nagar, Delhi 110017 India; \\ mbansalsac@rediff.com, prabhat.prbhakar@gmail.com \\ 2. Technical University of Munich, Arcisstraße 21,80333 München, Germany; akshat.gupta@tum.de
}

Received 22-V-2018. C Corrected 28-VII-2018. $\quad$ Accepted 28-IX-2018.

\begin{abstract}
Increasing urbanisation is widely associated with decline in biodiversity of all forms. The aim of the present study was to answer two questions: (i) Does rapid urbanization in Delhi (India) affect biodiversity of arbuscular mycorrhizal (AM) fungi? (ii) If so, how? We measured the AM fungal diversity at nine sites located in Delhi forests, which had different types of urban usage in terms of heavy vehicular traffic pollution, littering, defecation and recreational activities. The study revealed a significant decrease in AM fungal diversity (alpha diversity) and abundance measured as spore density, biovolume, mean infection percentage (MIP) in roots, soil hyphal length and easily extractable glomalin related soluble proteins (EE-GRSP) at polluted sites. Non-metric multidimensional scaling (NMDS) and nested PERMANOVA, revealed significant differences in AM fungal community structure which could be correlated with variations in soil moisture, temperature, $\mathrm{pH}$, carbon, and nitrogen and phosphorus levels. BEST (biota and environmental matching) analysis of biological and environmental samples revealed that soil temperature and moisture accounted for $47.6 \%$ of the total variations in the samples. The study demonstrated how different forms of human activities in urban ecosystems of Delhi are detrimental to the diversity and abundance of AM fungi.
\end{abstract}

Key words: arbuscular mycorrhizal fungi; Urban forests; Glomus; Glomeromycotina; in situ conservation; anthropogenic disturbance.

Gupta, M. M., Gupta, A., \& Kumar, P. (2018). Urbanization and biodiversity of arbuscular mycorrhizal fungi: The case study of Delhi, India. Revista de Biología Tropical, 66(4), $1547-1558$.

Increasing urbanisation is widely associated with decline in biodiversity of all forms by introducing new man-made stresses which affect the occurrence of species in a variety of ways. Arbuscular mycorrhizal (AM) fungi of subphylum Glomeromycotina (Spatafora, Chang, Benny, Lazarus, \& Smith 2016) are important soil organisms with many ecosystem roles. They form a symbiotic partnership with most of the land plants to increase their effective absorptive capabilities and recieve plantderived photosynthates from them (Walder \& van der Heijden, 2015). Abundant scientific evidence exists to demonstrate that AM fungi improve soil attributes leading to better tree/ shrub seedling survival, growth and establishment on moisture and nutrient stressed and degraded soils (reviewed by Asmelash, Bekele, \& Birhane, 2016) in all environments including urban ecosystems (Chaudhary, Sandall, \& Lazarski, 2018). These beneficial organisms, however, have not received adequate attention concerning their own biodiversity and conservation. Proper attention given to these microrganisms would have an implication in many conservation priority approaches such 
as reserve selection procedures, afforestation / reforestation drives (Pagano \& Cabello, 2011).

The factors that drive the occurrence and distributions of AM fungi have been extensively studied (e.g., Davison, Moora, Öpik, Adholeya, \& Ainsaar, 2015; Powell \& Bennett, 2016). Earlier studies revealed that the factors which contribute to global biodiversity loss, such as habitat loss, pollution (Bedini, Pellegrino, Avio, Pellegrini, \& Bazzoffi, 2009; Brundrett \& Ashwath, 2013; Yang, Liang, Han, Chiu, \& Ghosh, 2016), invasive species (Souza, Rodriguez-Echeverría, Andrade, \& Freitas, 2016) and global warming (Drigo, Pijl, Duyts, Kielak,\& Gamper, 2010; Dumbrell, Ashton, Aziz, Feng, \& Nelson, 2011) may also be detrimental to these fungi. Different anthropogenic activities affect the biodiversity of AM fungi in an ecosystem to the extent of causing a conservation concern for many species (reviewed by Álvarez-Sánchez, Johnson, Antoninka, Chaudhary, \& Lau, 2011). Recent studies on multiscale effects of anthropogenic disturbance in the form of clearcutting on the distribution of a AM fungi in tropical rain forests revealed marked changes in AM fungal communities which later could be stabilized (García de León et al., 2018). A comparison in mycorrhizal status of forest trees grown in urban and rural environments in Poland revealed much lesser colonization in urban areas (Tyburska, Frymark-Szymkowiak, Kulczyk-Skrzeszewska, \& Kieliszewska-Rokicka, 2013). However, effect of specific polluting human activities as a result of urbanisation in city forests have yet not been explored in regard to its influence on the below-ground diversity of AM fungi. These activities may be posing a conservation concern for these fungi in India (Turrini \& Giovannetti 2012). Such studies would have important implications on improving city life.

High population density and the ensuing overuse of scarce resources have put heavy pressure on the soil environment in Delhi, India. Since arbuscular mycorrhizal (AM) fungi are the organisms that live in the soil, they are sensitive to factors that cause soil disturbance and their response is not always predictable (van der Heyde, Ohsowski, Abbott, $\&$ Hart, 2017). Different species of AM fungi have been shown to be differntially sensitive to different agricultural practices (Oehl, Sieverding, Ineichen, Ris, \& Boller, 2005, Tchabi, Hountondji, Laouwin, Coyne, \& Oehl, 2009), heavy metal pollution, elevated $\mathrm{CO}_{2}$ concentration and climate warming (Drigo et al.2010, Dumbrell et al.2011). The stress of urban pollution on soil as a result of change in land usage pattern may also be affecting the occurrence of these fungi. In all, occurrence of 167 species of the total of $\sim 250$ morphologically described species belonging to the phylum Glomeromycota are known to occur in India (Gupta, Naqvi \& Singh, 2014; Gupta, Naqvi \& Kumar, 2017). Nevertheless, studies on the biodiversity of AM fungi concerning their protection and conservation have yet not begun in several parts of the world including India.

In the present study, we aimed to explore the combined effect of different forms of unattended recreational, defecation, littering and air polluting anthropogenic activities associated with urbanisation on the biodiversity pattern of AM fungi in urban forests of Delhi. We hypothesised that these activities are altering the soil and air quality that leads to change in the AM fungal community structure. We predicted that some AM fungal species would be more sensitive to the variations caused by these factors and would thus be of a conservation concern. Our study is unique because we examined the variation in AM fungal species biodiversity, abundance and community structure to assess the influence of several unexplored anthropogenic activities in reserve forest stands of Delhi with a focus on conservation. A better understanding of the range of variability in different AM fungal species across these parameters will enhance our ability to predict distributions and aid in designing efforts to conserve the biodiversity and ecosystem functions of this important group of fungi. 


\section{MATERIALS AND METHODS}

Sampling design: The abundance, diversity and community composition of Glomeromycota was examined in the urban forest area across the Delhi Ridge $\left(21^{\circ} 38^{\prime} \mathrm{N} \& 77^{\circ} 12^{\prime}\right.$ E), which is the northern extension of the ancient Aravalli Ranges ( 1500 million years old), with vegetation classified as 'thorny scrub' (Sinha, 2014). The Ridge stretches over a distance of $35 \mathrm{~km}$ across Delhi in India, which includes green belt, recreational sites (parks) and villages inhabited by rural populations. The Ridge is known to be a good store of AM fungi (Rani \& Mukerji, 1990). In this study, we examined the combined effect of different unattended polluting anthropogenic activities associated with urbanisation on AM fungal biodiversity.

Nine experimental sites were selected for the present study, which differed in terms of exposure to littering (dumping garbage), defecation (urine and faeces), recreation (especially morning walk and picnic) and vehicular traffic by native population. All the sites were similar in terms of geological and meteorological conditions and were located in Delhi Ridge area (Digital Appendix 1). They had a common occurrence of trees of Acacia nilotica / Prosopis juliflora apart from other native vegetation. In order to quantify the cumulative effect of the different forms of urban usage on AM fungal diversity and abundance, the investigated sites were categorised into three a priori groups based on visual assessment of their use: protected (gp-1), recreational (gp-2) and polluted (gp-3) urban disturbance (UD) sites (Table 1). The protected sites had none of the four disturbances and were protected by iron fencing or concrete wall. They had minimum of urban disturbances. Sites grouped as gp-3 (polluted sites) had presence of three of the polluting criteria namely littering, defecation and vehicular traffic by urban population and were not protected by any fencing. However, the gp- 2 sites were regions of recreational activities such as morning walk, picnic, playing etc. and had a boundary wall.

Hierarchical sampling was done for sample collection from each site belonging to three UD groups. There were three groups of UD, three sites within each group, three plots in each site and three samples from each plot were taken, and two observations thus totalling 162 samples (Fig. 1). Sites referred to a location of about $2000 \mathrm{~m}^{2}$ area with distinct urban exploitation features, plots referred to an area of $1 \mathrm{~m}^{2}$ under the canopy of Acacia nilotica / Proposis julifora from where the soil samples were collected. Undisturbed core samples were collected (soil and roots) from each site, from a depth of $0-30 \mathrm{~cm}$, using a core sampler $(7.62$ $\mathrm{cm}$ in diameter) on the same day in winter season (December 2015). The observations were repeated after one year. The samples were airdried in shade to the point where there was no

TABLE 1

Summary of observed variation in various diversity and abundance parameters across urban disturbance and region factors*

\begin{tabular}{lccc}
\multicolumn{1}{c}{ Character } & UD & Site (UD) & Intercept \\
Alpha diversity & $6.112(0.036)$ & $28.669(.000)$ & $130.404(0.00)$ \\
Density & $\mathrm{NS}$ & $18.588(000)$ & $29.230(0.002)$ \\
Biovolume & $5.205(0.049)$ & $5.395(0.000)$ & $49.231(0.00)$ \\
MIP & $\mathrm{Ns}$ & $8.256(0.00)$ & $175.5(0.00)$ \\
EE-GRSP & $65.453(0.00)$ & $\mathrm{Ns}$ & $1201.323(0.0)$ \\
Soil hyphae & $8.21(0.020)$ & $4.883(0.00)$ & $179.052(0.00)$ \\
Spore community & $2.69(0.006)$ & $22.61(0.001)$ & NA \\
\hline
\end{tabular}

* Values are ANOVA F-statistics with $p$-values in parenthesis. For urban disturbance (UD) factor nested ANOVA was done and nested PERMANOVA was performed for spore community significance analysis. Values for spore community analysis by PERMANOVA are pseudo F and $\mathrm{P}$ (perm) in the bracket. NS = not significant NA = not applicable. 


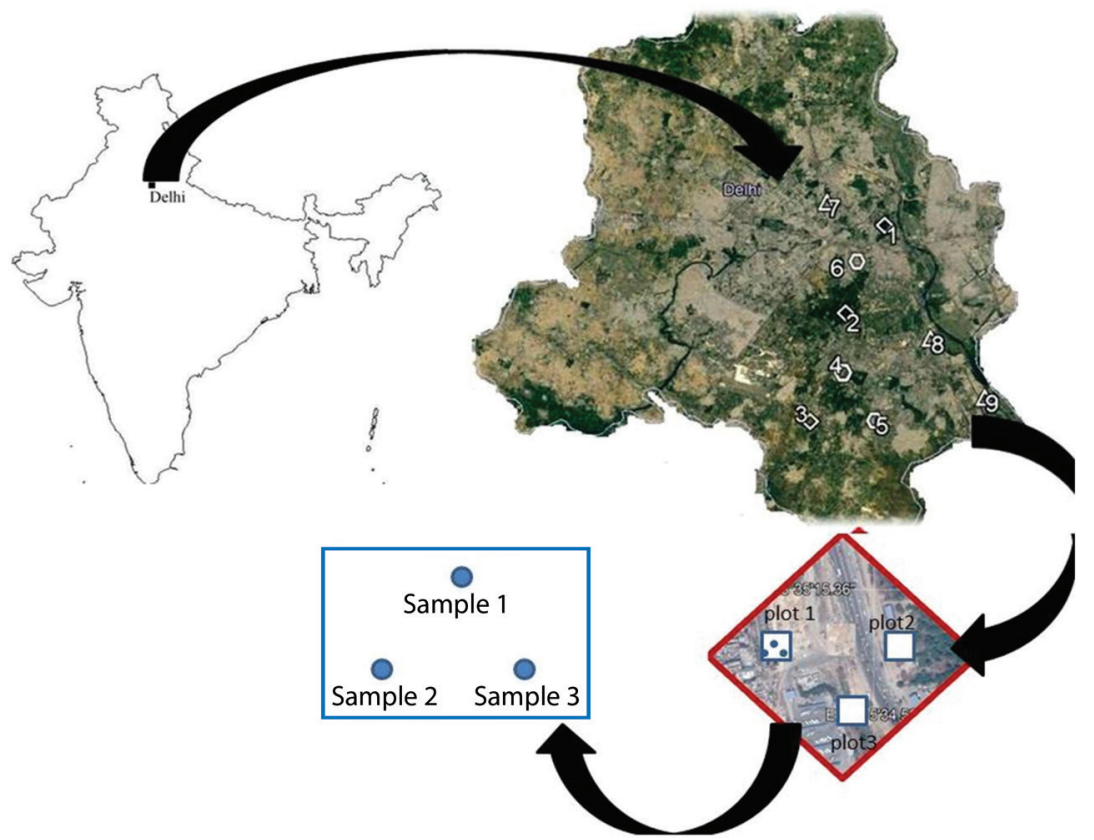

Fig. 1. Sampling design and location of sampling sites within the Delhi Ridge area, India. Different symbols are used for different groups of sites (gp-1 $>$; gp-2 $\triangle$; gp-3 $\bigcirc$ ).

free moisture and were stored in plastic bags. All 162 samples from 27 plots were used for AM fungal spore isolation, characterisation, and quantifying soil environmental parameters.

AM fungal assessment: The focus of the study was on biodiversity and conservation of AM fungi, thus, it was reasonable to use morphological method of AM fungal identification rather than the molecular methods. Additional parameters were studied to capture the broadest possible image of AM fungal structure and function in the study area, namely, mean infection percentage (MIP), spores biovolume and number, hyphal length, and activity by measuring easily extractable glomalin related soluble proteins (EE-GRSP) concentration. The spores were isolated using wet sieving and decanting with sieves of decreasing size $(719 \mu \mathrm{m}, 250$ $\mu \mathrm{m}, 106 \mu \mathrm{m}$ and $53 \mu \mathrm{m}$ ) (Daniels \& Skipper, 1982). Fine roots (diameter $<2 \mathrm{~mm}, 1 \mathrm{~cm}$ long root fragment and 100 root segments) retained on top sieve were stained by Trypan blue following the method of Phillips and Hayman
(1970). MIP percent colonisation was calculated by the method of McGonigle, Miller, Evans, Fairchild, \& Swan (1990). The abundance of AM fungal spores was measured as spore density (number/50 g soil). It was observed that the large sized spores $(>200 \mu \mathrm{m}$ diameter) were present in much smaller number, so as to give them proper representation, the spore biovolume parameter was preferred as a measurement for AM fungal abundance in the soil (Brundrett, Bougher, Dell, \& Grove, 1996). Spore biovolume was equal to $4 / 3 \pi r^{3} d$ where, $r$ was radius of spore and $d$ was spore density (number of spores per gram of soil). Radius of the spore $r$, was average of 10 spores. Soil hyphae for microscopic observation were isolated following the method described by Brundrett et al. (1996) with certain modifications as given in Shen, Hedley, Camps Arbestain, \& Kirschbaum (2016). Hyphal density was quantified by agitating $5 \mathrm{~g}$ of soil in a blender, siphoning the suspension with a pipette, and then collecting hyphal fragments on a membrane filter. The hyphae that were angular and aseptate in 
appearance and 1.0-13.4 $\mu \mathrm{m}$ in diameter were deemed to be of AM fungal in origin, and only those were considered for the measurements (Brundrett et al., 1996). Determination of EEGRSP was carried out following the procedure as described by Zou, Chen, Srivastava, Wang, \& Xiang (2016). Procedurally, 1 g dry soil sample was incubated in $8 \mathrm{ml} 20 \mathrm{mM}$ citrate (pH 7.0) at $121^{\circ} \mathrm{C}$ and $0.11 \mathrm{mpa}$ for $30 \mathrm{~min}$ and centrifuged at $10000 \mathrm{~g}$ for $3 \mathrm{~min}$. The supernatant was utilized for the assay of the EE-GRSP concentration according to Bradford (1976).

The AM fungal species diversity was assessed as alpha diversity calculated as number of morph species detected per soil sample for each site. Multi spore and single spore cultures were raised in autoclaved soil by the method of Walker (1999). Detailed protocol of species identification is available in supplementary material (Digital Appendix 2 and Digital Appendix 4).

Environmental data: Soil temperature was directly measured using wood-covered soil thermometer (Sita Thermometers Industries, Uttar Pradesh India). Soil pH, was measured using digital Elico $\mathrm{pH}$ meter, after suspending soil in water $(1: 2.5)$. Soil moisture content was determined using gravimetric method (ovendrying method). The available phosphorus was determined using Olsen's method (1954). Percent $\mathrm{C}$ and $\mathrm{N}$ were determined by $\mathrm{CHN}$ analyser (Thermo Finnigan, FLASH EA 1112 series at IIT Mumbai India).

Statistical analyses: Effect of human intervention factor on different AM fungal assessment parameters was assessed by Nested ANOVA to evaluate the fixed effect of urban disturbance and random effects of sites nested within UD (Neter, Kutner, Nachtsheim, \& Wasserman, 1996). To satisfy the criteria for ANOVA, tests were conducted on mean values such that sites were replicates. Tukey's HSD multiple comparison tests with a 0.05 were used to determine differences between groups of means. All ANOVAs and multiple comparisons were performed with SPSS statistics software
(SPSS Inc, 2008). Nested ANOVA was also done to check the significance of variation in mean values of environmental parameters.

Community structure analyses: Nonmetric multidimensional scaling (nMDS) was used to visually summarize the main trends in similarities among samples and for studying the relation between biological and environmental samples. Nested PERMANOVA was used to compare groups of objects and test the hypothesis. All nMDS ordinations, nested PERMANOVA and Principal component analysis (PCA), RELATE and BEST (biota and environmental matching), were performed with Primer 7 Statistical Software (Clarke \& Gorley, 2015). Detailed protocol of each step is given in supplementary material (Digital Appendix 3).

\section{RESULTS}

Negative effect of urban disturbance on Glomeromycota diversity: The study AM fungal diversity measurement at the different sites indicated that the highest diversity (alpha diversity) was observed at the sites with least urban disturbance i.e. in their natural protected habitats (gp-1) (Fig. 2A). The average alpha diversity, i.e. the direct measurement of number of morpho species per sample, was 13.66 for (gp-1) compared to 8.33 and 6.33 at gp-2 (recreation) and gp-3 (polluted) sites respectively. Gamma diversity i.e. the total number of species detected over the entire study area was 29 species, which belonged to 10 genera of AM fungi (Fig. 3). On an average 8 to10 species were found at each site with a maximum of 21 species were isolated from one sample in a plot located at Sanjay Van (site 3) and minimum being two species isolated from one sample from polluted site located at Anand Vihar (site 8). Variations in alpha diversity of AM fungi because of urban disturbances were significant statistically (Nested ANOVA, P < 0.05). Eight species were isolated exclusively from protected sites. The group wise Venn-diagram plotted on the basis of AM fungal species presence/ absence data, revealed only three species were 

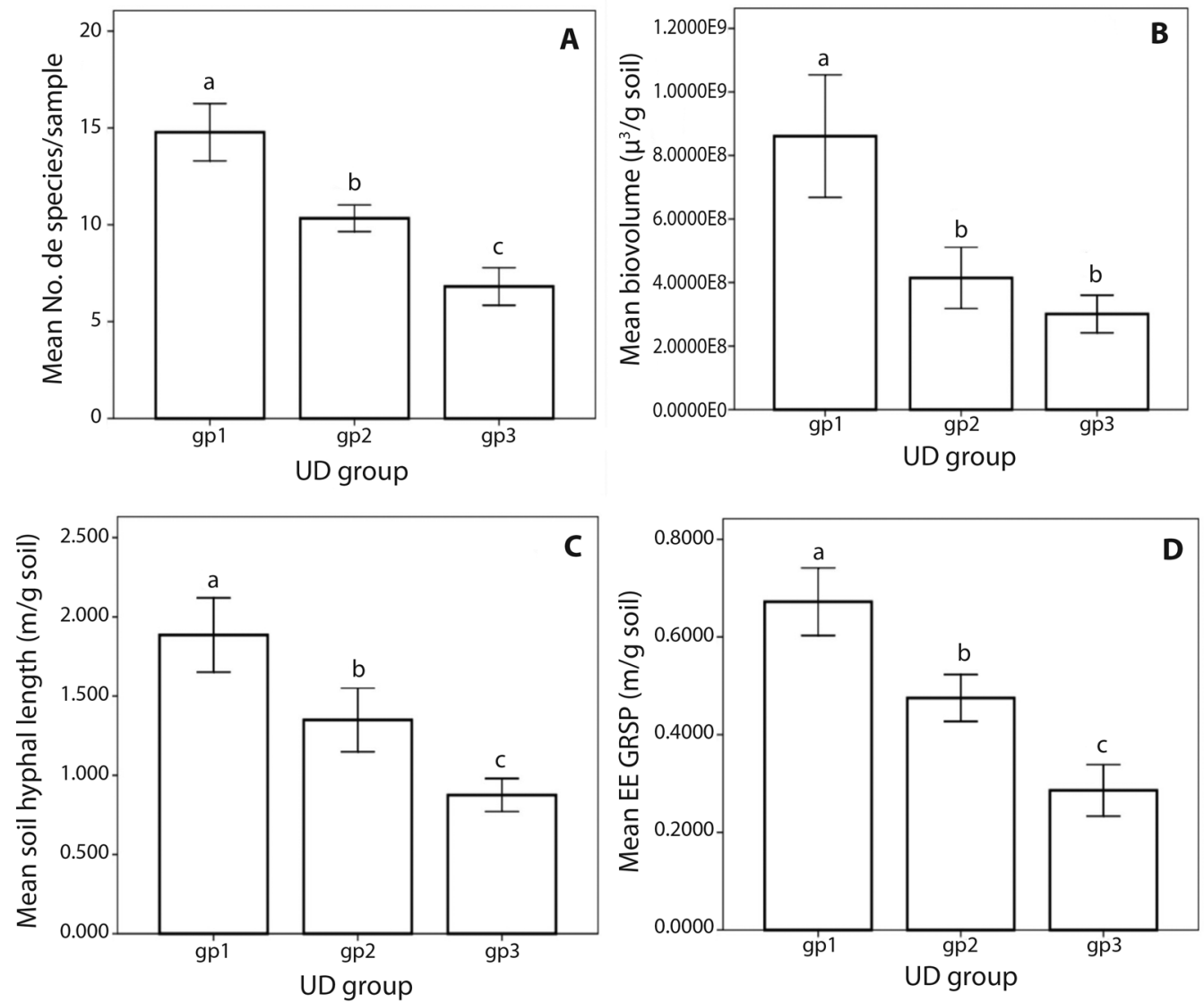

Fig. 2. Effect of urban disturbance on alpha diversity (A), biovolume (B), soil hyphal length (C) and EE-GRSP (D) assay of AM fungi isolated from nine sites located at Delhi Ridge.

absent from protected sites (Digital Appendix 3, Digital Appendix 4, Digital Appendix 5 and Digital Appendix 6). Glomus constrictum was present in all the samples from all the sites across Delhi ridge. Three species namely like Diversispora aurantia, Entrophospora infrequens and Glomus macrocarpum were isolated from all three urban disturbance groups but their frequency varied among samples.

Negative effect of urban disturbance on AM Fungal abundance: There was a negative influence of the studied factors on AM fungal abundance; however, the impact varied with the parameter studied. The mean AM fungal spore density was highest in protected sites $(298.3$ spores $/ 50 \mathrm{~g}$ of soil) almost double of the one present in polluted sites (gp3) (Supplementary material Fig. 2A). In general, the species which produced large spores $(>200 \mu \mathrm{m})$ were much less represented over the entire study area. The size-based disparity in spore number of species was apparent even after biovolume parameter was taken in to consideration (Fig. 2B). A heat map drawn based on spore size revealed that there was an apparent disappearance of AM fungi with large sized spores $(>200 \mu \mathrm{m})$ and smaller $(50 \mu \mathrm{m})$ spores from the polluted sites (Fig. 3). The spores belonging to order Glomerales with size range of 80 to $160 \mu \mathrm{m}$ were much better adapted to the study area and were evenly distributed all over the study area.

Mean values of the other studied AM fungal abundance parameters i.e soil hyphal length 


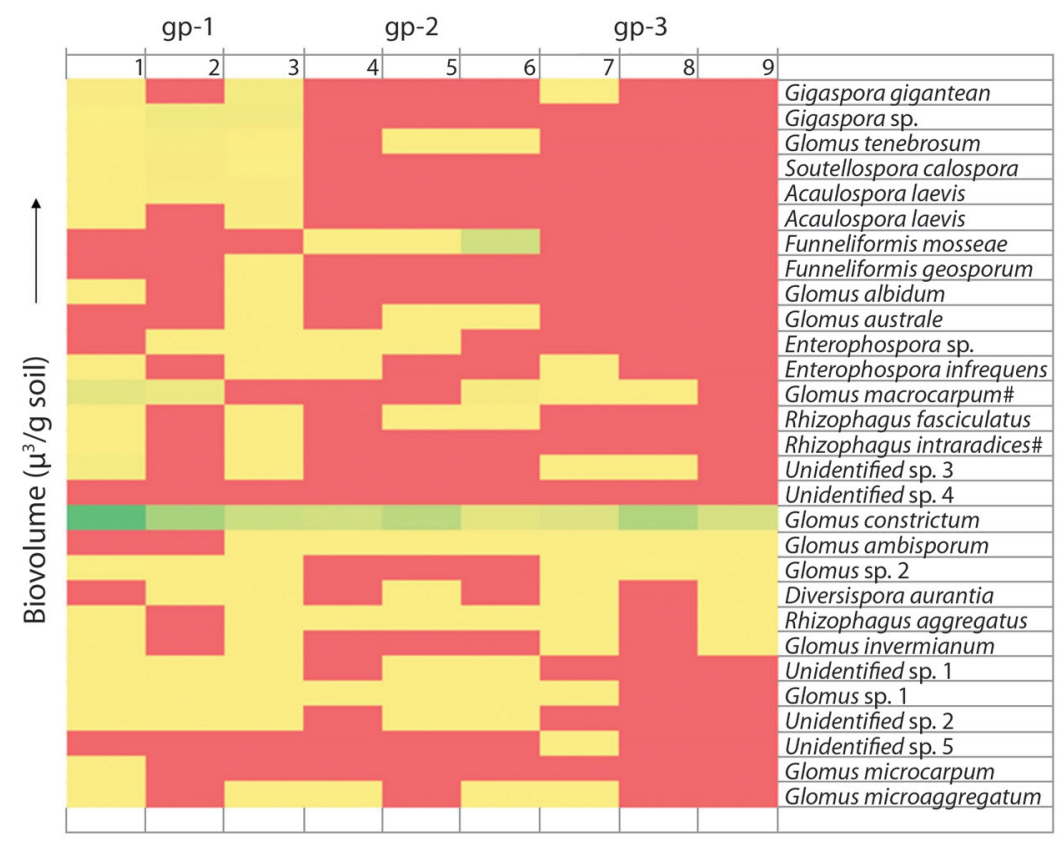

Fig. 3. Heat map table displaying the variation in biovolume of AM fungal spores in different urban disturbance groups (generated with MS excel conditional formatting based on their values; shades of red color depicts minimum, yellow moderate and green maximum biovolume values).

(Fig. 2C) and EE-GRSP concentration (Fig. 2D) followed a similar trend. The values of all three parameters were highest in protected (gp-1) sites and were more consistent. Nested ANOVA P-value revealed statistically significant variations in the mean values of hyphal length and EE-GRSP concentration in soil (Table 1). The random effects of sites nested within UD were statistically significant for all parameters studied except for EE-GRSP.

\section{Urban disturbances also change the AM} fungal community structure: nMDS ordination plots drawn for spore abundance data with Bray-Curtis distance measure (density based) depicted a reasonably good separation between the samples from three UD groups at 2D stress of 0.17 , indicating that the composition of the AM fungal communities was different in the three groups (Fig. 4A). However, the samples in each group were scattered. Nested PERMANOVA revealed significant variations spore community data in the samples (Table 1). PCA of environmental data revealed that the first and second component accounted for 50.7 and $17.4 \%$ of variations respectiviely in the samples (Fig. 4B). There was a correlation in the pattern of similarity matrices of biological and environmental data (spearman rank correlation coefficient, 0.36). BEST analysis of correlation between biological and environmental samples revealed soil moisture and temperature together accounted for $47.6 \%$ of the total variations in the biological samples.

\section{DISCUSSION}

The present study revealed that anthropogenic disturbances of recreation, littering, defecation and vehicular pollution declined the diversity and abundance of AM fungal spores measured as alpha-diversity spore density, biovolume, mean infection volume, easily extractable glomalin related soluble proteins and soil hyphal length in Delhi Ridge forests. A change 

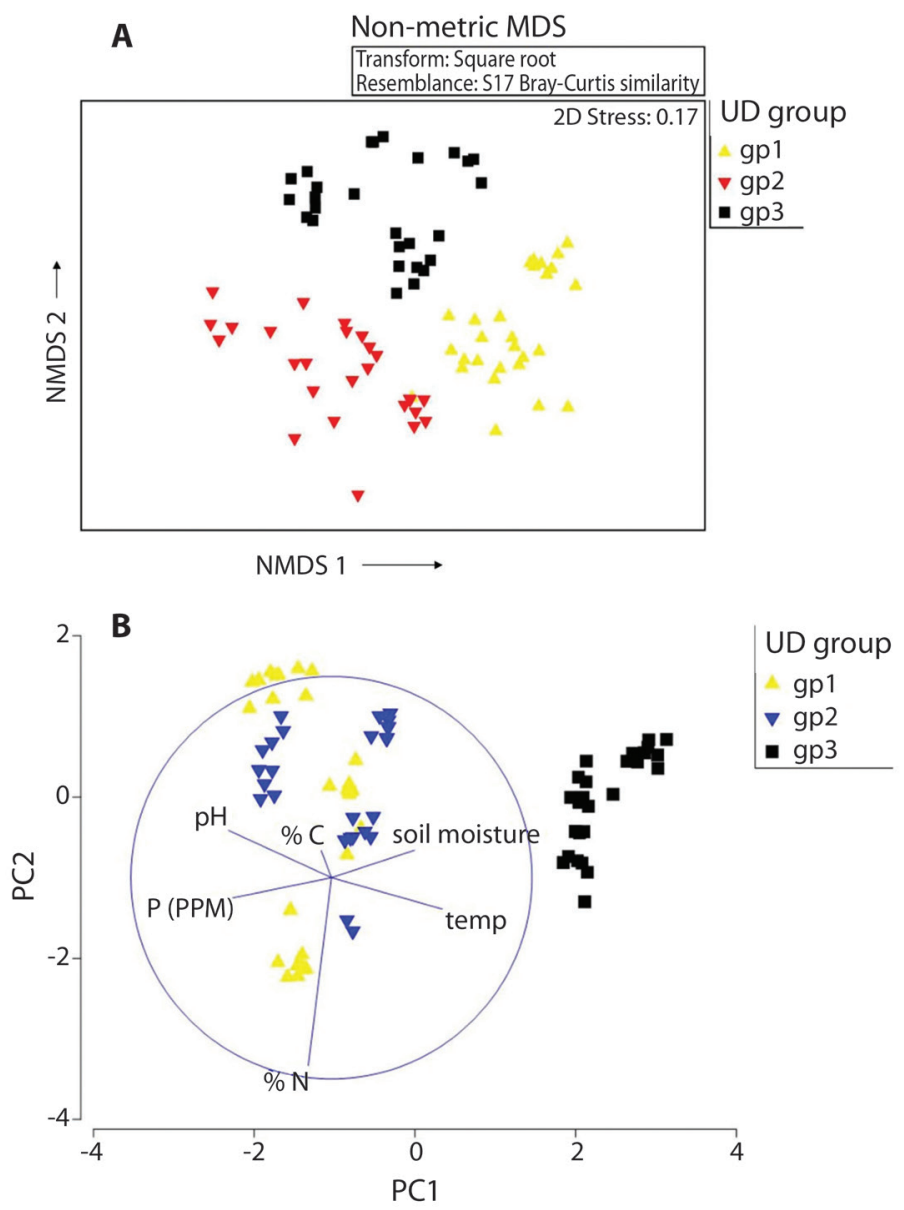

Fig. 4. A. NMDS plot of AM fungal communities in three HI groups. Each point represents the spore community. B- PCA of environmental data.

in Glomeromycotean community composition with urban disturbances was depicted by nMDS ordination plots and was best explained by soil moisture and temperature. Delhi ridge harboured a rich AM fungal flora in terms of high alpha and gamma diversity as reported earlier (Rani \& Mukerji, 1990).

The main highlight of the present study was that members of Glomeromycota which produced large-spores $(>200 \mu \mathrm{m})$ were found to be more sensitive to the variations caused by these disturbances. Three large-spored species, namely Acaulospora laevis, Gigaspora sp. and Scutellospora calospora were isolated only from protected sites with minimum urban disturbances. This corroborated with earlier studies, where, large sized members of the order Diversisporales, such as Gigaspora gigantea, Gigaspora margarita, Scutellospora calospora and Racocetra beninesis have been shown to be sensitive to different agricultural practices (Oehl et al. 2005, Tchabi et al., 2009). Environmental pollution parameters such as heavy metal pollution, elevated $\mathrm{CO}_{2}$ concentration and climate warming have also been shown to influence a particular group of AM fungi (Drigo et al., 2010, Dumbrell et al., 2011). Recently, van der Heyde et al. (2017) found evidence for differential response among AM fungal species to anthropogenic disturbances 
and certain species were especially susceptible to certain type of disturbance. The relative dominance of members of the order Glomerales and the higher sensitivity of the large spored species of AM fungi in forest soils of Delhi might be because of their trade-off in resource allocation either by many small or fewer large spores, with each having a similar colonisation capacity (Brundrett \& Ashwath, 2013). It may also be a part of a life-history strategy for the different AM families (Varela-Cervero, LópezGarcía, Barea, \& Azcón-Aguilar, 2016; van der Heyde et al., 2017). Inclusion of the biovolume parameter in the analysis suggested that the AM fungi that produce larger spores produce them in smaller numbers suggesting resource allocation optimisation. Yet, the large spored AM fungi are poorly represented in Delhi ridge forests. There seemed to be a better adaptability of species belonging to the genus Glomus, which produce spores (size 80-160 $\mu \mathrm{m}$ ) in much large numbers.

In the present study, it was hypothesised that the interfering anthropogenic activities would alter the AM fungal community structure by change in the soil quality. The study indicated that cumulative negative effect of soil moisture and temperature because of littering, urination and feces by the urban population could explain $47.6 \%$ of the variations in samples collected from sites belonging to different UD groups. The effect of urination and defecation on the growth of soil microorganisms has been well documented (Bertram, Orwin, Clough, Condron, \& Sherlock, 2012), but it has not been studied for AM fungi. Recently Hart, Antunes, Chaudhary, \& Abbott (2018), based on synthesized data from literature added that anthropogenic nitrogen deposition is exposing plants and the associated AM fungi to elevated $\mathrm{N}$ availability is often leading to shifts in AM fungal communities. Variation in the production of AM fungal spores is also observed to be influenced by soil phosphorus and other nutrient conditions (Chaudhary, O'Dell, Rillig, \& Johnson, 2014; Davison et al., 2015). Host plant species influence the communities of AM fungi by hosting different AM fungal taxon, identities and richness via root exudates (Lekberg \& Waller, 2016; Gupta, Aggarwal, \& Asha 2018). There seemed to be other unexplored factors operating at different sites that brought about significant variations in the results.

A major limitation in the present study was the inability to quantify each urban factors of littering, mechanical damage and pollution in natural field environment separately and to estimate their independent contributions to the responses. However, the present study extended our knowledge about the biodiversity of AM fungi with reference to the anthropogenic activities in urban forests of Delhi, maintained to offer a variety of ecosystem services such as biodiversity conservation, removal of atmospheric pollutants, oxygen regeneration, microclimate regulation and soil stabilisation (Sinha, 2014). The study pointed towards the need to focus on below ground diversity of AM fungal symbiosis, which plays a vital role in mitigating climate change and preventing erosion (Asmelash et al., 2016; Treseder, 2016). Additionally, anthropogenic interferences affect the different taxa of AM fungi differently which might lead to disappearance of certain group of these fungi. Conservation projects that include strategies to preserve AM fungi for future generation are not reported in India. The trend of in situ conservation of AM fungi had already begun in 2008, when first in situ collection of AM fungi was established in Italy (Turrini, Avio, Bedini, \& Giovannetti, 2008; Turrini \& Giovannetti, 2012) with the aim of preserving AM fungal diversity occurring in Italian sand dune ecosystem. There is a need to restore the abiotic conditions and promote the recolonization of AM fungi.

\section{ACKNOWLEDGMENTS}

Authors (MMG and PK) duly acknowledges the financial support from University Grants Commission as a major research project (MRP-MAJOR-BOTA-2013-21235). We are thankful for several undergraduates in the project who were very helpful in data collection and field trips. 


\section{RESUMEN}

Urbanización y biodiversidad de hongos micorrízicos arbusculares -Caso de estudio de Delhi, India. El incremento en la urbanización está ampliamente asociado con una disminución de la biodiversidad de todas las formas. El objetivo del presente estudio fue responder dos preguntas: (i) ¿Afecta la urbanización rápida en Delhi (India) la biodiversidad de hongos micorrízicos arbusculares (MA)?, y (ii) si es así, ¿Cómo? Medimos la diversidad de hongos MA en nueve sitios ubicados en los bosques de Delhi, los cuales tenían diferentes tipos de uso urbano en términos de contaminación por alto tráfico vehicular, basura, defecación y actividades recreacionales. El estudio reveló una disminución significativa en la diversidad de hongos MA (diversidad alfa) y abundancia medida como densidad de esporas, biovolumen, porcentaje medio de infección (PMI) en raíces, longitud de las hifas del suelo y glomalina fácilmente extraible relacionada con proteínas solubles (EE-GRSP) en sitios contaminados. Análisis de escalamiento multidimensional no métrico (NMDS) y PERMANOVA anidados revelaron diferencias significativas en la estructura de hongos MA, que puede estar relacionada con la variación en humedad, temperatura, $\mathrm{pH}$ y niveles de carbono, nitrógeno y fósforo del suelo. El análisis BEST (biota y correspondencia ambiental) de muestras biológicas y ambientales mostró que la temperatura y humedad del suelo explican un $47.6 \%$ del total de la variación en las muestras. Este estudio demostró cómo las diferentes actividades humanas en ecosistemas urbanos de Delhi son perjudiciales para la diversidad y abundancia de hongos MA.

Palabras clave: hongos micorrízicos arbusculares; bosques urbanos; Glomus; Glomeromycotina; conservación in situ; alteración antropogénica.

\section{REFERENCES}

Álvarez-Sánchez, J., Johnson, N. C., Antoninka, A., Chaudhary, V. B., Lau, M. K., Owen, S. M., ... \& Castillo, S. (2011). Large-scale diversity patterns in spore communities of arbuscular mycorrhizal fungi. Mycorrhiza: occurrence and role in natural and restored environments. Nova Science Publishers, Hauppauge, $33-50$.

Asmelash, F., Bekele, T., \& Birhane, E. (2016). The potential role of arbuscular mycorrhizal fungi in the restoration of degraded lands. Frontiers in Microbio$\log y, 7,1095$.

Bedini, S., Pellegrino, E., Avio, L., Pellegrini, S., Bazzoffi, P., Argese, E., \& Giovannetti, M. (2009). Changes in soil aggregation and glomalin-related soil protein content as affected by the arbuscular mycorrhizal fungal species Glomus mosseae and Glomus intraradices. Soil Biology and Biochemistry, 41(7), 1491-1496.
Bertram, J. E., Orwin, K. H., Clough, T. J., Condron, L. M., Sherlock, R. R., \& O'Callaghan, M. (2012). Effect of soil moisture and bovine urine on microbial stress. Pedobiologia, 55(4), 211-218.

Bradford, D. M. M. A. (1976). A Rapid and Sensitive Method for Quantitation of Microgram Quantities of Protein Utilizing the Principle of Protein-Dye Binding. European Journal of Anaesthesiology, 25, 248-254. DOI:10.1006/abio.1976.9999

Brundrett, M., Bougher, N., Dell, B., \& Grove, T. (1996). Working With Mycorrhizas in Forestry and Agriculture. Australia: Australian Centre for International Agricultural Research.

Brundrett, M. C., \& Ashwath, N. (2013). Glomeromycotan mycorrhizal fungi from tropical Australia III. Measuring diversity in natural and disturbed habitats. Plant and Soil, 370(1-2), 419-433.

Chaudhary, V. B., Sandall, E. L., \& Lazarski, M. V. (2018). Urban mycorrhizas: predicting arbuscular mycorrhizal abundance in green roofs. Fungal Ecology. DOI: 10.1016/j.funeco.2018.03.002

Chaudhary, V. B., O’Dell, T. E., Rillig, M. C., \& Johnson, N. C. (2014). Multiscale patterns of arbuscular mycorrhizal fungal abundance and diversity in semiarid shrublands. Fungal Ecology, 12, 32-43.

Clarke, K., \& Gorley, R. (2015). PRIMER v7: User manual/tutorial. Plymouth, UK: PRIMER-E Ltd.

Daniels, B. A., \& Skipper, H. D. (1982). Methods for the recovery and quantitative estimation of propagules from soil [Vesicular-arbuscular mycorrhizal fungi]. In N.C. Schenck (Ed.), Methods and Principles of Mycorrhizal Research (pp. 29-35). St Paul Minnesota, USA: American Phytopathological Society.

Davison, J., Moora, M., Öpik, M., Adholeya, A., Ainsaar, L., Bâ, A. ... \& Johnson, N. C. (2015). Global assessment of arbuscular mycorrhizal fungus diversity reveals very low endemism. Science, 349(6251), 970-973.

Drigo, B., Pijl, A. S., Duyts, H., Kielak, A. M., Gamper, H. A., Houtekamer, M. J., ... \& Kowalchuk, G. A. (2010). Shifting carbon flow from roots into associated microbial communities in response to elevated atmospheric $\mathrm{CO}_{2}$. Proceedings of the National Academy of Sciences, 107(24), 10938-10942.

Dumbrell, A. J., Ashton, P. D., Aziz, N., Feng, G., Nelson, M., Dytham, C., ... \& Helgason, T. (2011). Distinct seasonal assemblages of arbuscular mycorrhizal fungi revealed by massively parallel pyrosequencing. New Phytologist, 190(3), 794-804.

García de León, D., Davison, J., Moora, M., Öpik, M., Feng, H., Hiiesalu, I., ... \& Sepp, S. K. (2018). Anthropogenic disturbance equalizes diversity levels 
in arbuscular mycorrhizal fungal communities. Global Change Biology, 24(6), 2649-2659.

Gupta, M. M., Aggarwal, A. \& Asha (2018). From mycorrhizosphere to rhizosphere microbiome: The paradigm shift. In B. Giri, R. Prasad, \& A.Verma (Eds.), Root Biology (pp. 487-500). Springer Cham.

Gupta, M. M., Naqvi, N., \& Kumar, P. (2017). i AMFCentralized database of arbuscular mycorrhizal distribution, phylogeny and taxonomy. Journal of Recent Advances in Applied Sciences, 30(1), 1-5.

Gupta, M. M., Naqvi, N. S., \& Singh, V. K. (2014). The state of arbuscular mycorrhizal fungal diversity in India: an analysis. Sydowia, 66, 265-288.

Hart, M. M., Antunes, P. M., Chaudhary, V. B., \& Abbott, L. K. (2018). Fungal inoculants in the field: Is the reward greater than the risk? Functional Ecology, $32(1), 126-135$.

Lekberg, Y., \& Waller, L. P. (2016). What drives differences in arbuscular mycorrhizal fungal communities among plant species? Fungal Ecology, 24, 135-138.

McGonigle, T. P., Miller, M. H., Evans, D. G., Fairchild, G. L., \& Swan, J. A. (1990). A new method which gives an objective measure of colonization of roots by vesicular-arbuscular mycorrhizal fungi. New phytologist, 115(3), 495-501.

Neter, J., Kutner, M. H., Nachtsheim, C. J., \& Wasserman, W. (1996). Applied linear statistical models (Vol. 4). Chicago: Irwin.

Oehl, F., Sieverding, E., Ineichen, K., Ris, E. A., Boller, T., \& Wiemken, A. (2005). Community structure of arbuscular mycorrhizal fungi at different soil depths in extensively and intensively managed agroecosystems. New Phytologist, 165(1), 273-283.

Olsen, S. R. (1954). Estimation of available phosphorus in soils by extraction with sodium bicarbonate. Washington: United States Department of Agriculture.

Pagano, M. C., \& Cabello, M. N. (2011). Mycorrhizal interactions for reforestation: Constraints to Dryland Agroforest in Brazil. ISRN Ecology, 2011.

Phillips, J. M., \& Hayman, D. S. (1970). Improved procedures for clearing roots and staining parasitic and vesicular-arbuscular mycorrhizal fungi for rapid assessment of infection. Transactions of the British mycological Society, 55(1), 158-IN18.

Powell, J. R., \& Bennett, A. E. (2016). Unpredictable assembly of arbuscular mycorrhizal fungal communities. Pedobiologia, 59(1-2), 11-15.
Rani, R. E. K. H. A., \& Mukerji, K. G. (1990). The distribution of vesicular-arbuscular mycorrhizal fungi in India. Acta Microbiologica Hungarica, 37(1), 3-7.

Shen, Q., Hedley, M., Camps Arbestain, M., \& Kirschbaum, M. U. F. (2016). Can biochar increase the bioavailability of phosphorus? Journal of Soil Science and Plant Nutrition, 16(2), 268-286.

Sinha, G. N. (2014). An introduction to the Delhi Ridge. Department of Forest and Wildlife, Government of National Capital Territory of Delhi, New Delhi.

Souza, T. A. F. D., Rodríguez-Echeverría, S., Andrade, L. A. D., \& Freitas, H. (2016). Could biological invasion by Cryptostegia madagascariensis alter the composition of the arbuscular mycorrhizal fungal community in semi-arid Brazil? Acta Botanica Brasilica, 30(1), 93-101.

Spatafora, J. W., Chang, Y., Benny, G. L., Lazarus, K., Smith, M. E., Berbee, M. L., ... Stajich, J. E. (2016). A phylum-level phylogenetic classification of zygomycete fungi based on genome-scale data. Mycologia, 108(5), 1028-1046. DOI: 10.3852/16-042

SPSS Inc. (2008). SPSS Statistics for Windows (Version 17.0). Chicago: SPSS Inc.

Tchabi, A., Hountondji, F., Laouwin, L., Coyne, D., \& Oehl, F. (2009). Racocetra beninensis from sub-Saharan savannas: a new species in the Glomeromycetes with ornamented spores. Mycotaxon, 110(1), 199-209.

Treseder, K. K. (2016). Model behavior of arbuscular mycorrhizal fungi: predicting soil carbon dynamics under climate change. Botany, 94(6), 417-423.

Turrini, A., Avio, L., Bedini, S., \& Giovannetti, M. (2008). In situ collection of endangered arbuscular mychorrhizal fungi in a Mediterranean UNESCO Biosphere Reserve. Biodiversity and Conservation, 17(3), 643.

Turrini, A., \& Giovannetti, M. (2012). Arbuscular mycorrhizal fungi in national parks, nature reserves and protected areas worldwide: a strategic perspective for their in situ conservation. Mycorrhiza, 22(2), 81-97.

Tyburska, J., Frymark-Szymkowiak, A., Kulczyk-Skrzeszewska, M., \& Kieliszewska-Rokicka, B. (2013). Mycorrhizal status of forest trees grown in urban and rural environments in Poland. Ecological Questions, 18(1), 49-57.

van der Heyde, M., Ohsowski, B., Abbott, L. K., \& Hart, M. (2017). Arbuscular mycorrhizal fungus responses to disturbance are context-dependent. Mycorrhiza, 27(5), 431-440. 
Varela-Cervero, S., López-García, Á., Barea, J. M., \& Azcón-Aguilar, C. (2016). Differences in the composition of arbuscular mycorrhizal fungal communities promoted by different propagule forms from a Mediterranean shrubland. Mycorrhiza, 26(5), 489-496.

Walder, F., \& van der Heijden, M. G. (2015). Regulation of resource exchange in the arbuscular mycorrhizal symbiosis. Nature Plants, 1(11), 15159.

Walker, C. (1999). Methods for culturing and isolating arbuscular mycorrhizal fungi. Mycorrhiza News, $11(2), 2-4$
Yang, Y., Liang, Y., Han, X., Chiu, T. Y., Ghosh, A., Chen, H., \& Tang, M. (2016). The roles of arbuscular mycorrhizal fungi (AMF) in phytoremediation and treeherb interactions in $\mathrm{Pb}$ contaminated soil. Scientific Reports, 6, 20469.

Zou, Y. N., Chen, X., Srivastava, A. K., Wang, P., Xiang, L., \& Wu, Q. S. (2016). Changes in rhizosphere properties of trifoliate orange in response to mycorrhization and sod culture. Applied Soil Ecology, 107, 307-312.

See Digital Appendix at: / Ver Apéndice digital en:

revistas.ucr.ac.cr 